\title{
Effect of particle size and concentration on the feeding behaviour of adult pilchard Sardinops sagax
}

\author{
Carl David van der Lingen
}

Sea Fisheries Research Institute, Private Bag X2, Rogge Bay 8012, South Africa

\begin{abstract}
Laboratory experiments investigated the effect of food particle size and concentration on the feeding behaviour of adult pilchard Sardinops sagax. This species employs 2 methods of feeding: filterfeeding and particulate-feeding. Particles of less than $1230 \mu \mathrm{m}$ total length elicit a filtering response while larger particles elicit particulate-feeding at low concentrations and filter-feeding at high concentrations. Clearance rate during filtering is independent of particle size and concentration over the size range 393 to $1227 \mu \mathrm{m}$, with a mean value of $11.78 \pm 4.91 \mathrm{lfsh}^{-1} \mathrm{~min}^{-1}$. This value is $93 \%$ of the calculated maximum clearance rate for filtering fish, implying that pilchard are highly efficient at feeding over this size range. Particles of less than $206 \mu \mathrm{m}$ are cleared at reduced rates, with retention efficiency inversely proportional to particle size. Clearance rates during particulate-feeding are greater than those for filtering, and increase with increasing particle size to a predicted saturation value of $46.531 \mathrm{fish}^{-1} \mathrm{~min}^{-1}$ Pilchard display size-selectivity during particulate-feeding, preferentially removing larger prey items. Results indicate that pilchard is primarily a filter-feeder, obtaining the majority of its food from the smaller end of the size spectrum of available prey. Microzooplankton, and to a lesser extent phytoplankton, are major dietary components. This is in contrast to Cape anchovy Engraulis capensis, which is primarily a particulate-feeder and derives most of its food from the larger end of the size spectrum of available prey. The different feeding responses of these 2 co-occurring species are discussed with reference to resource partitioning.
\end{abstract}

KEY WORDS: Planktivorous fish - Feeding behaviour - Feeding selectivity - Filter-feeding Particulate feeding

\section{INTRODUCTION}

Members of the genus Sardinops currently constitute the largest single component of the global commercial fisheries harvest (Parrish et al. 1989). In the Benguela system, the pilchard Sardinops sagax (formerly $S$. ocellatus; Parrish et al. 1989) has been a major target of the purse-seine fishery, with annual catches peaking in excess of 1 million tonnes ( $t$ ) during the 1960s. In recent years catches have declined markedly to current levels of approximately $100000 \mathrm{t}$ for the South African and Namibian fleets combined (Armstrong \& Thomas 1989).

Previous field-based research examining the feeding biology of pilchard indicated that they were primarily filter-feeders showing an apparent 'preference' for phytoplankton, and having a mean ratio of phytoplankton to zooplankton in their stomachs of $2: 1$ by volume (Davies 1957). King \& Macleod (1976) sug- gested that juvenile pilchard were zooplanktophagous, feeding predominantly on calanoid copepods, but switching to phytoplanktivory at approximately $100 \mathrm{~mm}$ standard length (SL). Adult pilchard were regarded as essentially non-selective filter-feeders, the change from a selective zooplanktivorous to a nonselective phytoplanktivorous feeding regime being attributed to a decrease in porosity of the filtering mechanism (King \& Macleod 1976). James (1988a) considered pilchard to be capable of both filter- and particulate-feeding, and estimated that zooplankton accounted for 60 to $80 \%$ of the diet.

This study was conducted to investigate the effects of particle size and concentration on the feeding behaviour, selectivity and consumption rates of adult pilchard. The experimental approach reported here closely follows that of James \& Findlay (1989) for Cape anchovy, i.e. feeding the fish a wide variety of food organisms of different size and monitoring their result- 
ing feeding behaviour and clearance rates. A detailed comparison of the feeding behaviour of these 2 clupeoids can therefore be made, allowing an assessment of whether these co-existing species exhibit resource partitioning or direct competition for a common and occasionally limiting (Shannon \& Field 1985, Peterson et al. 1992) food resource.

The comparison may also provide some insights into the 'regime problem' - worldwide large-scale fluctuations in sardine and anchovy populations, with anchovy often abundant when sardine are scarce and vice versa (Lluch-Belda et al. 1989). Understanding the dynamics of trophic interactions between clupeoid species pairs, such as pilchard and anchovy, may permit a better understanding of this concept. In addition, the results obtained from this study will be used to construct an energy budget for pilchard.

\section{MATERIAL AND METHODS}

Adult pilchard $(229.3 \pm 10.3 \mathrm{~mm}$ total length, TL) were collected by dip-netting from Cape Town harbour. The fish were transported to the laboratory in 2001 black plastic drums and were transferred into $3000 \mathrm{l}$ tanks supplied with a continuous flow of $5 \mu \mathrm{m}$ filtered sea water at ambient temperature (17.2 \pm $1.6^{\circ} \mathrm{C}$ ). The fish were acclimated to laboratory conditions for 2 mo before being used in experiments. Fish were fed once a day on a coarsely grated frozen mixture of trout pellets supplemented with a vitamin premix, ascorbic acid and cod liver oil, bound with gelatine. Fish also received frozen euphausiids (Euphausia lucens) once a week.

Table 1. Summary of experimental food types and sizes used

\begin{tabular}{lc|}
\hline Food organism & Size $(\mu \mathrm{m})$ \\
\hline $\begin{array}{l}\text { Cultured } \\
\text { Artemia franciscana }\end{array} \quad$ \\
$\quad$ (nauplii to adults) & $393-6532$ \\
Brachionus plicatilis & $196-240$ \\
Tisbe spp. (nauplii) & $156 \pm 50$ \\
Thalassiosira weissflogii & $13 \pm 3$ \\
Skeletonema costatum & $17 \pm 5$ \\
Chaetoceros didymis & $46 \pm 11$ \\
& \\
Wild & \\
Centropages brachiatus & $873-1657$ \\
Calanus agulhensis & $1670-2790$ \\
Paracalanus parvus & $873 \pm 232$ \\
Evadne spinifera & $742 \pm 119$ \\
Noctiluca miliaris & $480-852$ \\
Skeletonema costatum (chains) & $117 \pm 39$ \\
\hline
\end{tabular}

Both cultured and wild plankton were used in the experiments (Table 1). Cultured zooplankton included brine shrimp Artemia franciscana (nauplii to adults), the rotifer Brachionus plicatilis, and the harpacticoid copepod Tisbe spp. The diatoms Thalassiosira weissflogii, Chaetoceros didymus and Skeletonema costatum were also cultured for use as experimental food. Natural plankton assemblages, consisting of copepod (Calanus agulhensis, Centropages brachiatus and Paracalanus parvus) and cladoceran (Evadne spinifera) species, the dinoflagellate Noctiluca miliaris, and chains of $S$. costatum were also offered to the fish. Natural zooplankton were captured using a drift-net of $200 \mu \mathrm{m}$ mesh, and were used immediately after collection. Natural phytoplankton were captured using a $37 \mu \mathrm{m}$ mesh Spanish net.

A single type and size-class of food particle was employed for 25 experiments. However, in order to determine whether pilchard selected prey on the basis of particle type or size, 6 experiments involving mixed size-classes of the same food type (e.g. Artemia franciscana nauplii and juveniles) or mixed size-classes of varied food types (e.g. natural zooplankton) were conducted. Two of these mixed size experiments were also 'multiple experiments', in which food concentrations in the tank were regularly replenished to approximately initial levels after being depleted by the fish.

Experiments consisted of introducing a known concentration of food particles into a tank containing a school of pilchard and observing the feeding response of the fish. Experiments were conducted in a $2 \mathrm{~m}$ diameter, $2500 \mathrm{l}$ capacity fibreglass tank situated under a $55 \%$ shadecloth roof. Schools of 15 pilchard were used for all experiments, each school being used for 7 consecutive experiments before being replaced to avoid habituation of the fish to experimental conditions. New fish introduced into the tank were acclimated for a minimum period of $1 \mathrm{wk}$ before experiments were initiated. Fish were starved for $2 \mathrm{~d}$ prior to experimentation to standardize hunger state.

The experimental apparatus consisted of the tank, the floor of which was marked with a grid of lines $10 \mathrm{~cm}$ apart, a video camera mounted above the tank, and a porous air tube which provided a continuous fine-bubble curtain around the perimeter of the tank. Prior to experimentation the volume in the tank was reduced to $1000 \mathrm{l}$ and the sea water supply switched off. Once the fish had resumed normal behaviour (cessation of the startle response) they were filmed for 15 min to determine non-feeding swimming speeds. The bubble curtain was then activated and the food added to the tank.

Preliminary experiments in the absence of fish showed that 3 min bubbling after the addition of food was sufficient to ensure homogeneous distribution of 
the particles. Food concentrations inside the tank were determined by subsampling immediately $(t=0)$ after the bubble curtain was discontinued, and at regular intervals thereafter. Two different sampling methods were used:

(1) Zooplankton subsamples were taken by means of a clear perspex tube $145 \mathrm{~mm} \mathrm{i.d.} \mathrm{for} \mathrm{small} \mathrm{zoo-}$ plankters < $1000 \mu \mathrm{m} \mathrm{TL}$, or $100 \mathrm{~mm}$ i.d. for large zooplankters $>1000 \mu \mathrm{m}$ TL) which mated with meshbottomed (37 $\mu \mathrm{m}$ for small zooplankters or $300 \mu \mathrm{m}$ for large zooplankters) cups placed randomly on the tank bottom. A constant volume integrating the entire water column was thus sampled and the food particles contained therein concentrated on the mesh. Food particles were collected from the mesh, preserved in $5 \%$ buffered formalin and stored for later examination. This technique did not reduce the water volume inside the tank, and did not disturb the fish overmuch. Preliminary experiments in the absence of fish showed that 5 subsamples were sufficient to determine the particle concentration inside the tank accurately (coefficient of variation never $>30 \%$ ). Food samples collected from mixed size-class or multiple experiments were size-fractionated using 900, 500 and $200 \mu \mathrm{m}$ meshes and the particles in each size-class were identified and counted.

(2) Phytoplankton subsamples were taken by randomly collecting five $200 \mathrm{ml}$ aliquots with a syringe from the tank. Concentrations were determined within $3 \mathrm{~h}$ of collection using a Coulter multi-sizer (orifice size $140 \mu \mathrm{m})$. Before enumeration, a pure sample of the phytoplankton was run through the multi-sizer in order to obtain a size-frequency profile and to identify the channels containing the particles. Three replicates from each aliquot were counted, giving 15 subsamples for each sampling time. Phytoplankton samples were also examined microscopically to determine average cell size and chain length.

Food concentration was measured at either 10 or 30 min intervals after cessation of bubbling. All replicates were counted and a mean concentration with standard deviation for each sampling time was calculated. Fifty individual food particles from each experiment were measured (maximum dimension) to determine average particle size.

Feeding behaviour was recorded with a video camera recording at 25 frames $\mathrm{s}^{-1}$. The fish were recorded for 5 min periods between each food sampling time (always 2 or 3 min after food sample) to assess their feeding behaviour. Each video sequence was analysed frame-by-frame to determine swimming speed, feeding intensity (\% of the school feeding) and feeding act (opening of the mouth combined with a flaring of the gills) duration. Swimming speed was determined by counting the number of frames taken by individual fish to completely cross one of the grid lines, and was expressed as body lengths per second. Thirty measurements of swimming speed were taken in each video sequence; only fish whose path did not deviate by more than approximately $20^{\circ}$ from their original heading during the counting period were considered. Feeding intensity was determined by measuring the proportion of the school feeding in a single randomly chosen frame when all 15 fish were clearly observable, and was repeated 20 times for each video sequence. Feeding act duration (FAD) was determined by counting the frames taken for a single feeding act. Five FAD subsamples of 20 observations each were taken from every video sequence.

Multiple experiments were conducted in a manner similiar to that described above, with the difference that food concentrations were replenished every 40 min to approximately original levels. Newly added food was mixed in the water by reactivating the bubble tube for $5 \mathrm{~min}$. Each run within a multiple experiment lasted $40 \mathrm{~min}$, with food samples being taken at $10 \mathrm{~min}$ intervals. Video sequences were taken as before.

Means and standard deviations for each of the data sets within each experiment were calculated for all time-intervals. Differences between the variables measured during the course of an experiment were determined by ANOVA/Tukey multiple range analysis, with statistical significance being accepted at the $\mathrm{p}<0.05$ level.

Clearance rates were determined for each time interval between significantly different food concentrations within each experiment, using the formula of Harvey (1937 in Friedland et al. 1984):

$$
F=\frac{V(\ln C i-\ln C f)}{t N}
$$

where $F$ is clearance rate $\left(1 \mathrm{fish}^{-1} \mathrm{~min}^{-1}\right), V$ is water volume (l), $C i$ and $C f$ are food concentrations at $t=i$ and $t=f$ respectively (no. of particles $1^{-1}$ ), $t$ is the interval between $t=i$ and $t=f$ (min), and $N$ is feeding intensity (average no. of fish feeding during $t$ ).

This formula was used in preference to that originally used by Frost (1972) and other authors (Gibson \& Ezzi 1985, James \& Findlay 1989) because Frost's (1972) formula assumes an unchanging instantaneous feeding intensity during the entire experimental period. As pilchard show a steady decline in feeding intensity after food introduction, the use of Frost's (1972) formula would lead to underestimation of the clearance rate.

The maximum theoretical clearance rate $\left(F_{\max }\right)$ was calculated from the formula:

$$
\begin{aligned}
F_{\max }= & \text { Mouth area } \times \text { Max. swimming speed } \\
& \text { when filter-feeding }
\end{aligned}
$$


Therefore, $F_{\max }$ can be used to evaluate filtration efficiency, $\% F_{\max }$ being the proportion of volume swept clear to volume filtered (Durbin \& Durbin 1975):

$$
\% F_{\max }=\left(F / F_{\max }\right) \times 100
$$

Clearance rates were plotted against particle size and against mean concentration $(\langle C\rangle)$ for particles of the same size. Mean concentration was calculated from the formula of Seale \& Beckvar (1980):

$$
<C>=\frac{C f-C i}{\ln (C f / C i)}
$$

where $\left\langle C>\right.$ is mean concentration (no. of particles $\mathrm{l}^{-1}$ ).

\section{RESULTS}

\section{Feeding behaviour}

Pilchard swim by means of the 'burst and glide' technique typical of clupeoid species (e.g. Engraulis mordax; Leong \& O'Connell 1969). For pilchard, the burst consisted of 1 to 6 tail beats and was followed by a glide of up to 8 body lengths (BL) duration. In the absence of food, pilchard swam in a roughly spherical school in the midwater of the tank. Swimming speeds for non-feeding fish were $0.87 \pm 0.46 \mathrm{BL} \mathrm{s}^{-1}\left(=20.0 \pm 10.6 \mathrm{~cm} \mathrm{~s}^{-1}\right)$.

When food particles were added to the tank, the initial response of the school was to break apart and for individuals to increase their swimming speed. At the same time the fish would begin to 'gulp' - flaring the opercula for short periods. These gulps were physically similiar to filtering acts, but were of a very limited duration, generally less than $0.5 \mathrm{~s}$. After a short (less than $1 \mathrm{~min}$ ) period of gulping, the fish would either begin to filter- or to particulate-feed. All phytoplankton and most zooplankton offered to the fish elicited a filtering response, regardless of prey concentration. Larger zooplankters elicited particulate feeding when present in low concentrations but a filtering response when present in high concentrations. These 2 feeding modes are described in more detail below.

\section{Filter-feeding}

Filter-feeding pilchard re-formed after the initial dispersion and swam in a tight school with their mouths opened wide and their opercula markedly flared. Each bout of filtering lasted on average $1.3 \mathrm{~s}$, ranging from 0.2 to $4.6 \mathrm{~s}$ (Fig. 1a). At the end of a filtering bout, the mouth and opercula were closed rapidly and quickly flared again. Typically the duration of the inter-filter period was $17 \%$ of the preceding filter-bout duration. When filter-feeding, the amplitude of the tail beat dur-

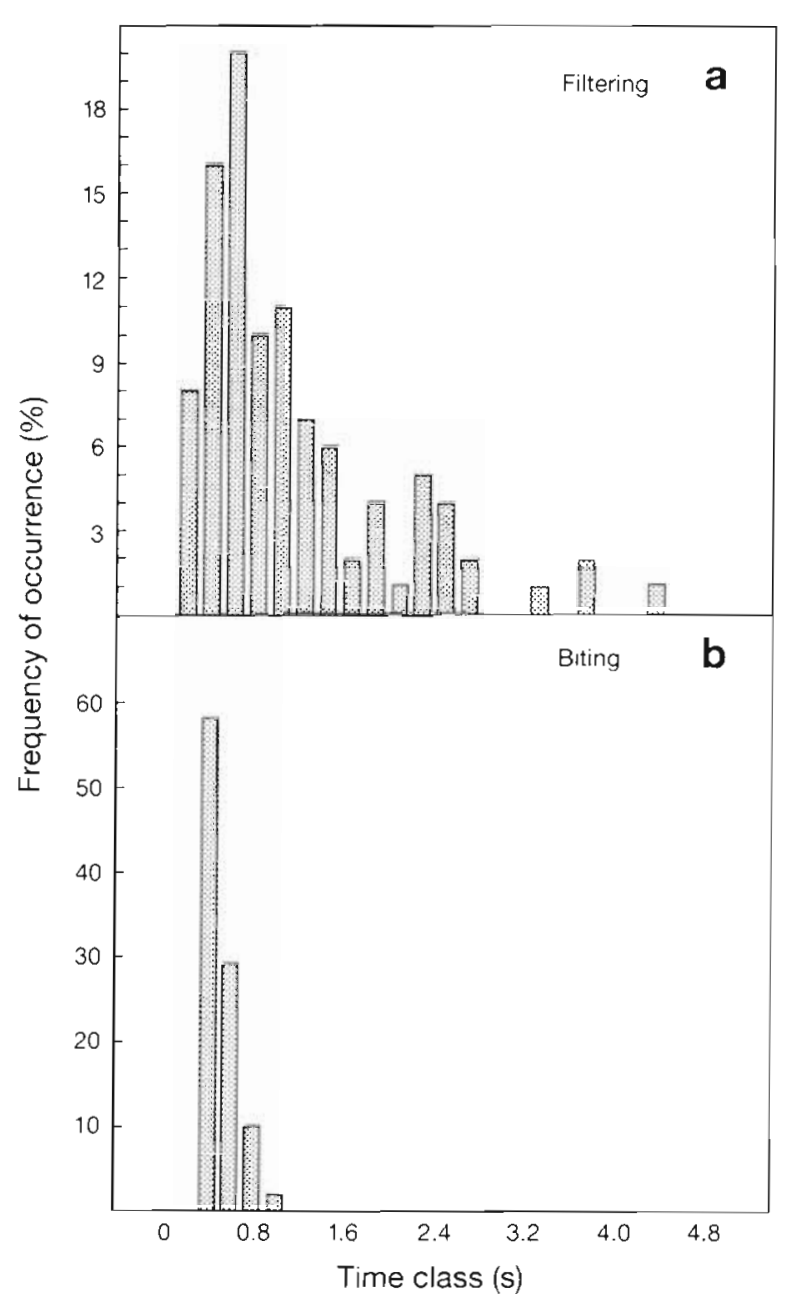

Fig. 1 Sardinops sagax. Frequency distributions of feedingact duration for different feeding modes of pilchard

ing the burst phase was much increased compared to non-feeding fish, and the glide phase coincided with the end of a particular filtering act. The school generally followed the curve of the tank and did not turn or change direction sharply. Fish at the leading edge of the school were invariably the most active filterers, while those towards the rear of the school filter-fed in a less intense fashion.

The results of 2 filter-feeding experiments are given in Fig. 2. Zooplankton concentrations declined exponentially (Fig. 2a), indicating that a constant proportion of food particles were being removed per unit time. When filter-feeding on zooplankton, pilchard initially increased their swimming speed from nonfeeding levels (Fig. 2b). During this initial period almost all of the fish in the school were filtering, with feeding intensities of over $80 \%$ being common (Fig. 2c). As food concentrations decreased, so too did swimming speeds and the proportion of the school feeding. 

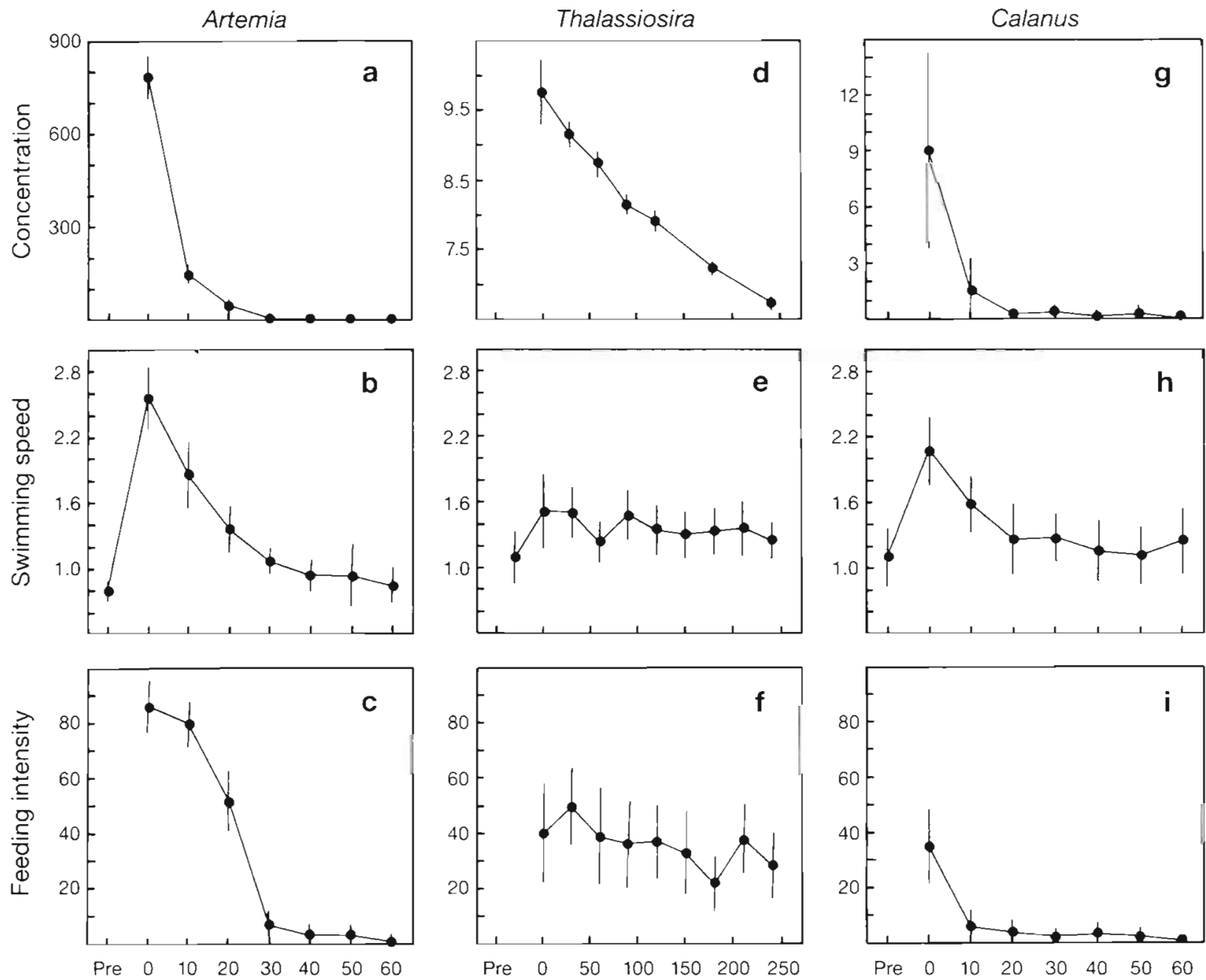

Time after food introduction (min)

Fig. 2. Sardinops sagax. Feeding responses of pilchard to various food types. (a to c) Filter-feeding on Artemia franciscana nauplii $(487 \pm 38 \mu \mathrm{m})$ : (a) particle concentration $\left(\right.$ no. $\left.\mathrm{l}^{-1}\right)$; (b) fish swimming speed (body lengths, BL, $\mathrm{s}^{-1}$ ); (c) feeding intensity $(\%$ of school feeding). (d to f) Filter-feeding on Thalassiosira weissflogii cells $(13 \pm 3 \mu \mathrm{m})$ : (d) particle concentration (no. $\left.\times 10^{3} \mathrm{ml}^{-1}\right)$; (e) fish swimming speed (BL s ${ }^{-1}$ ); (f) feeding intensity (\% of school feeding). ( $\mathrm{g}$ to i) Particulate-feeding on Calanus agulhensis adults $(2479 \pm 462 \mu \mathrm{m})$ : $(\mathrm{g})$ particle concentration (no. $\left.\mathrm{l}^{-1}\right)$; (h) fish swimming speed $\left(\mathrm{BL} \mathrm{s}^{-1}\right)$; (i) feeding intensity (\% of school teeding). Means $\pm 2 \mathrm{SD}$ are shown

The response of pilchard feeding on phytoplankton presented a very different picture. Particle concentrations decreased very slowly, and were seldom significantly different from one sample to the next (Fig. 2d). This indicated that the fish were less efficient at removing these particles. There was no significant increase in swimming speed after the introduction of food, as was the case for fish filter-feeding on zooplankton (Fig. 2e). Feeding intensity was never initially as high as when filter-feeding on zooplankton, but a substantial proportion ( 25 to $40 \%$ ) of the school exhibited filtering behaviour when offered diatoms (Fig. 2f). This proportion remained fairly constant over the entire experimental period.

\section{Particulate-feeding}

Particulate-feeding was characterized by a rapid opening and closing of the mouth accompanied by a partial flaring of the opercula. The opercula were never flared as wide as during filtering. Each bite lasted on average $0.4 \mathrm{~s}$ (Fig. 1b). When particulate feeding, the fish did not school but executed independent motions as they aligned themselves towards specific food particles. Changes in direction were thus frequent.

Fig. 2 depicts the results from an experiment where a particulate-feeding response was elicited from the fish. Prey concentration decreased dramatically after 
the introduction of food (Fig. 2g). Swimming speed increased significantly from non-feeding levels (Fig. 2h), but rapidly returned to non-feeding levels once the food had been depleted. Feeding intensity also decreased rapidly after the reduction in food concentration (Fig. 2i).

\section{Feeding mode switch}

The transition from filter- to particulate-feeding was gradual, increasing particle size resulting in a concomitant increase in the proportion of bites by feeding fish (Fig. 3). There was, however, a distinct difference between the threshold particle size (above which biting became the dominant feeding mode) for cultured and wild zooplankton, being approximately $3060 \mu \mathrm{m}$ TL and $1310 \mu \mathrm{m}$ TL respectively. This marked disparity is ascribed to differences in the appearance and behaviour of the prey organisms. Copepods are able to swim rapidly and show a welldeveloped escape response compared with Artemia franciscana. Therefore, to catch the larger wild zooplankton, pilchard were required to align themselves visually with respect to the prey particle, i.e. to par-

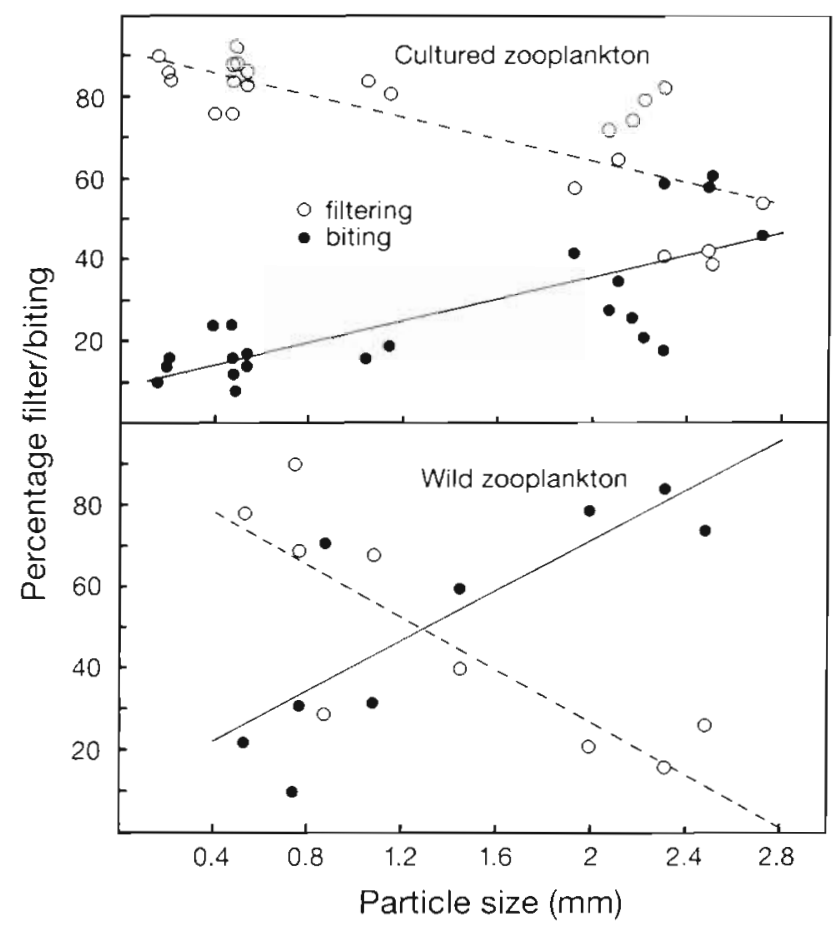

Fig. 3. Sardinops sagax. Relationship between proportion of feeding fish filtering (---) or biting (-) and particle size. Cultured zooplankton: \% filtering $=-0.014$ (Particle size) $+91.29 ; \%$ biting $=0.014$ (Particle size $)+8.71_{i} \mathrm{r}^{2}=0.60 i$ $\mathrm{p}<0.01$. Wild zooplankton: \% filtering $=-0.031$ (Particle size) $+90.36 \%$ biting $=0.031$ (Particle size $)+9.64 ; r^{2}=0.66 ; p<0.01$ ticulate-feed. The shift from filtering to biting was not only size- and prey type-dependent, but was also affected by particle concentration. High concentrations of large zooplankters (e.g. a swarm of mysids Mysidopsis major) elicited a filtering response from the fish.

\section{Feeding rates}

Clearance rates for filter-feeding pilchard were independent of particle size over the range 393 to $1227 \mu \mathrm{m}$ ( $t$-test: $t=1.77, \mathrm{n}=110, \mathrm{p}>0.05 ;$ Fig. 4 ) and had a mean value of $11.78 \pm 4.91(n=110) l \mathrm{fish}^{-1} \mathrm{~min}^{-1}$. This value is $93 \%$ of the calculated $F_{\max }$ value of $12.74 \mathrm{l} \mathrm{fish}^{-1}$ $\mathrm{min}^{-1}$, indicating that the pilchard are maximally efficient at filtering over this size range. Clearance rates were identical for fish filter-feeding on both cultured (e.g. Artemia franciscana, Brachionus plicatilis) and wild (e.g. Evadne spinifera) zooplankton particles. Clearance rate during filter-feeding was also independent of mean concentration $(<C>)$ for particles of similar size ( $t$-test: $t=0.10, \mathrm{n}=21, \mathrm{p}>0.05$; Fig. 5).

Below particle sizes of $206 \mu \mathrm{m} \mathrm{TL}$, clearance rates declined as the efficiency of small particle retention decreased (Fig. 6). Rotifers (Brachionus plicatilis, $204 \mu \mathrm{m} \mathrm{TL})$ were cleared at a rate of $6.34 \pm 2.39(\mathrm{n}=14)$ 1 fish $\left.^{-1} \mathrm{~min}^{-1}\right)$. Clearance rates on cultured diatoms (13 to $17 \mu \mathrm{m} \mathrm{TL}$ ) were $0.28 \pm 0.09(\mathrm{n}=11) 1 \mathrm{fish}^{-1} \mathrm{~min}^{-1}$, demonstrating that the fish were extremely inefficient at retaining these small particles. Pilchard were more efficient at retaining the chains of wild Skeletonema costatum $(117 \pm 55 \mu \mathrm{m} \mathrm{TL})$, showing a clearance rate of $3.57 \pm 1.20(\mathrm{n}=3) 1 \mathrm{fish}^{-1} \mathrm{~min}^{-1}$.

Clearance rates by fish particulate-feeding on particles greater than $1445 \mu \mathrm{m}$ TL ranged from 11.14

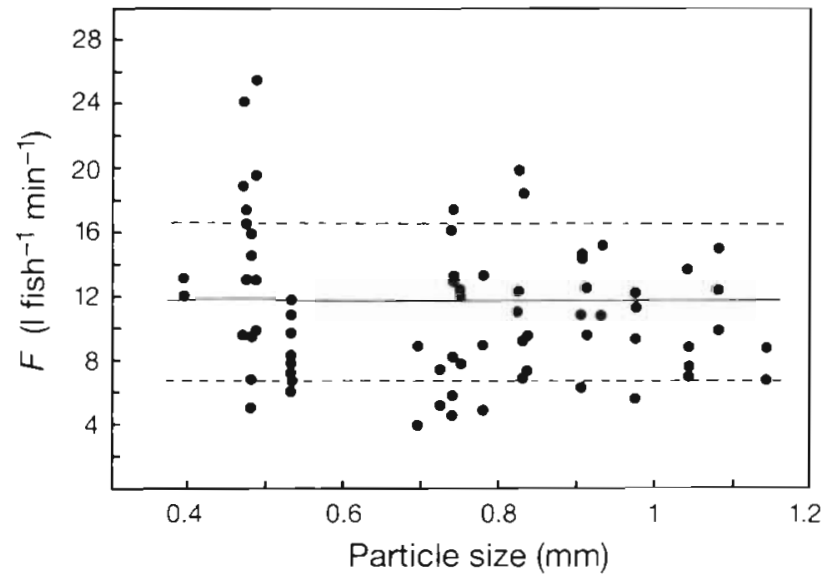

Fig. 4. Sardinops sagax. Clearance rate $(F)$ as a function of particle size (393 to $1227 \mu \mathrm{m}$ ) for filter-feeding pilchard. Solid line indicates mean clearance rate, dashed lines indicate $2 \mathrm{SD}$ 


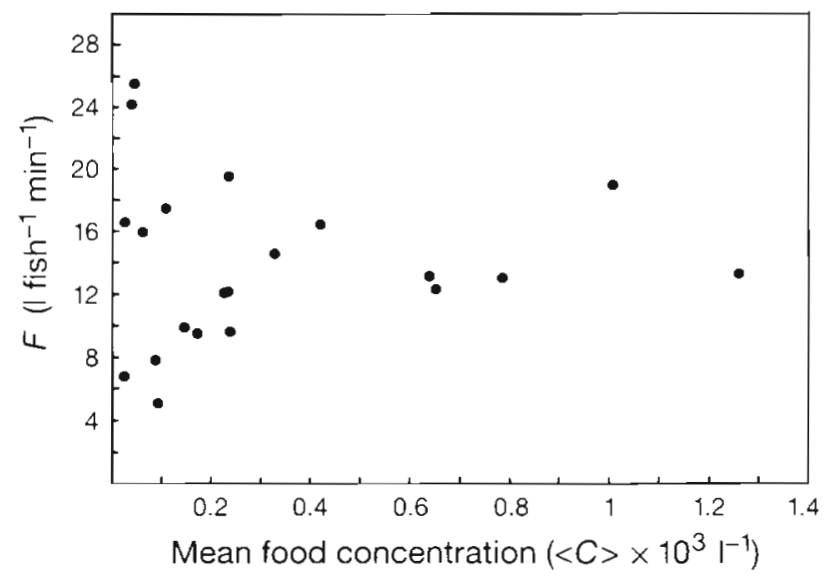

Fig. 5. Sardinops sagax. Clearance rate $(F)$ as a function of mean particle concentration for pilchard filter-feeding on Artemia franciscana nauplii $(492 \pm 42 \mu \mathrm{m})$

to $62.111 \mathrm{fish}^{-1} \mathrm{~min}^{-1}$, larger food particles being removed at a faster rate. Combination of the results for both types of feeding response (excluding the data for particulate-feeding on large Artemia franciscana, which are considered invalid for the reasons discussed above) allows a predictive equation of clearance rate as a function of particle size to be constructed. A fifth-order polynomial, with no discontinuity between filter- and particulate-feeding clearance rates, was found to provide a highly significant $(t$-test: $t=18.74, \mathrm{n}=175, \mathrm{p}<0.001)$ and representative curve. Predicted clearance rate reached a saturation value of $46.531 \mathrm{fish}^{-1} \mathrm{~min}^{-1}$ (Fig. 7).

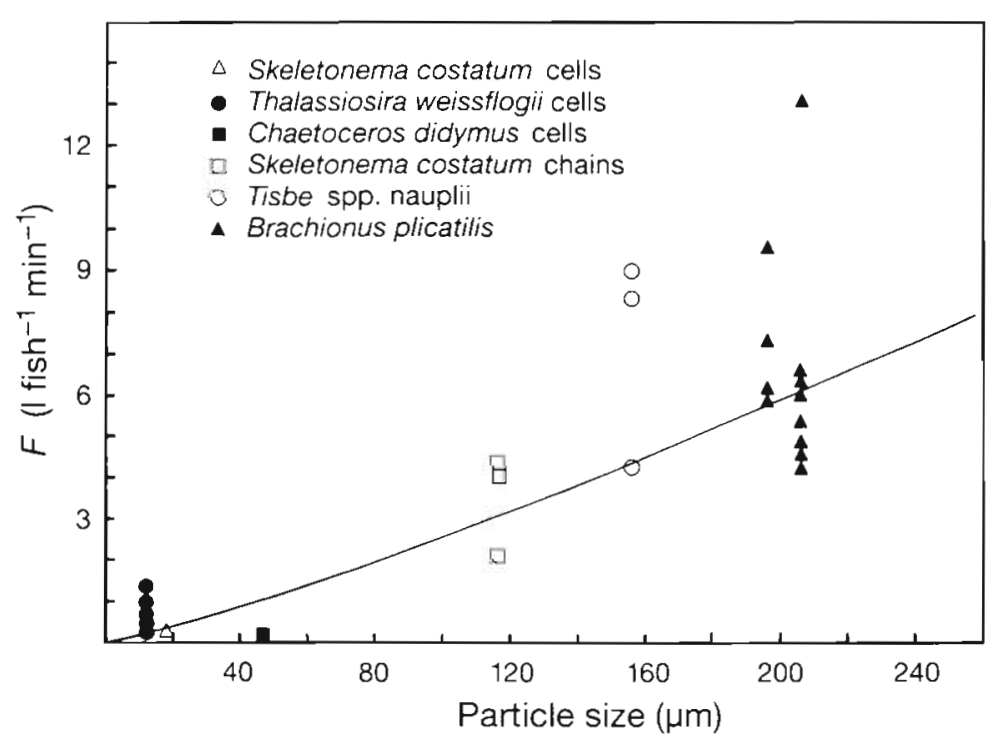

Fig. 6. Sardinops sagax. Clearance rate $(F)$ as a function of particle size for pilchard feeding on phytoplankton and microzooplankton. The fitted regression line $\left.[F=0.0112 \text { (Particle size })^{1.19} ; r^{2}=0.91 ; p<0.001\right]$ is shown

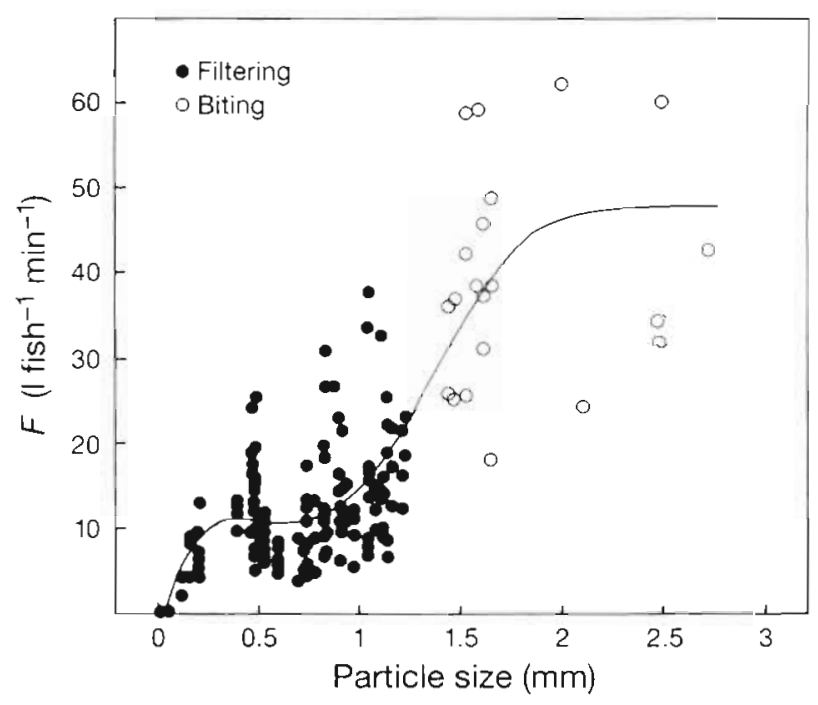

Fig. 7. Sardinops sagax. Clearance rate $(F)$ as a function of particle size for both feeding modes of pilchard. The fitted regression line $[F=-2.5421+0.0939$ (Particle size) -0.0002 (Particle size $)^{2}+\left(2.3829 \times 10^{-7}\right)(\text { Particle size })^{3}-\left(9.7258 \times 10^{-11}\right)($ Particle size $\left.)^{4}+\left(1.3623 \times 10^{-14}\right)(\text { Particle size })^{5} ; r^{2}=0.67 ; p<0.001\right]$ is shown

\section{Selective feeding}

The results obtained from the experiments employing mixed food demonstrate that pilchard can feed selectively, removing larger particles preferentially. Fig. 8a depicts the relative proportion by number of 3 sizeclasses of wild zooplankton in sequential samples from a multiple mixed experiment. Significant differences in relative proportions are apparent for all 3 size-classes (Table 2). The largest class (retained by a $900 \mu \mathrm{m}$ mesh: $>900 \mu \mathrm{m}$ ) showed a marked decline in relative proportion between all samples, the middle size-class (retained by a $500 \mu \mathrm{m}$ mesh: $>500 \mu \mathrm{m}$ ) showed a less significant decrease, while the small. est class (retained by a $200 \mu \mathrm{m}$ mesh: $>200 \mu \mathrm{m}$ ) showed a highly significant increase in relative proportion between the first 2 sample pairs, but no increase thereafter. In this experiment, the $>900 \mu \mathrm{m}$ and $>500 \mu \mathrm{m}$ size-classes were composed of adult (1545 $\pm 311 \mu \mathrm{m} \mathrm{TL})$ and juvenile (1152 $\pm 252 \mu \mathrm{m}$ TL) Centropages brachiatus respectively, while the $>200 \mu \mathrm{m}$ size-class consisted of Evadne spinifera (873 $\pm 143 \mu \mathrm{m}$ TL). During the initial part of each run ( $t=0$ to $t=10 \mathrm{~min}$ ) filtering was the dominant mode of feeding, but from $t=10$ min onwards biting became dominant, presumably being directed at the remaining zooplankters of the middle size-class (Fig. 8b). 


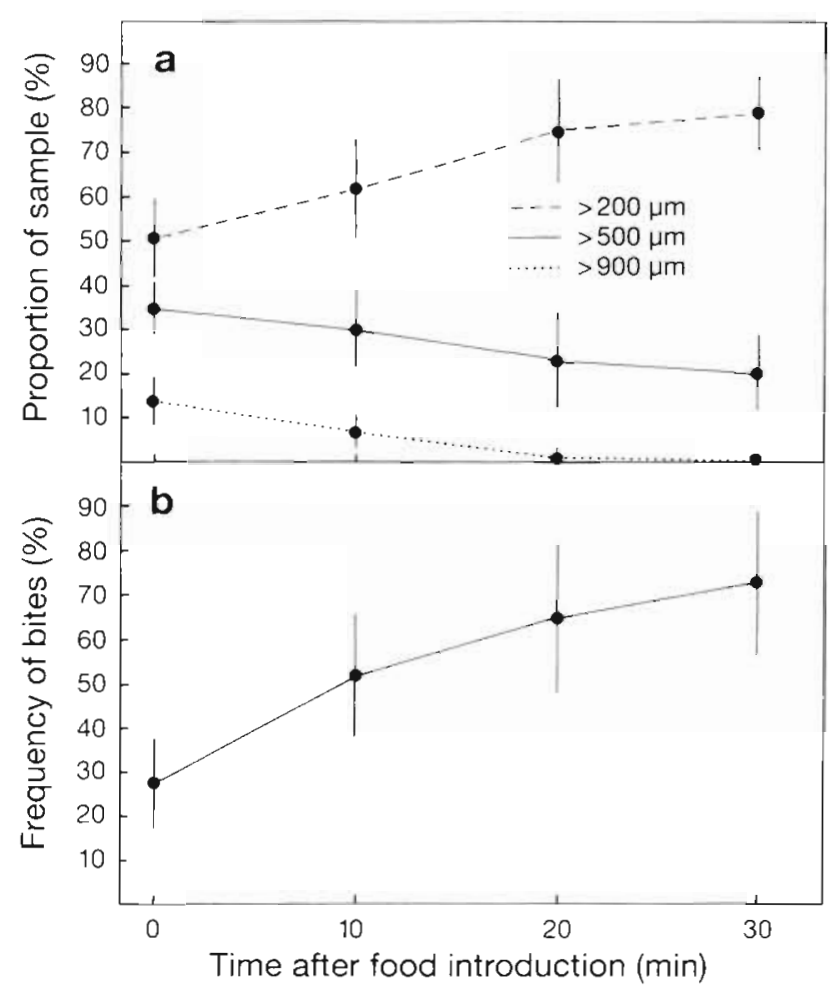

Fig. 8. Sardinops sagax. Feeding response of pilchard to mixed food assemblages. (a) Proportion of sample at various times after food introduction for 3 size-classes of wild zooplankton; large (>900 $\mu \mathrm{m}$ : adult Centropages brachiatus $1545 \pm 311 \mu \mathrm{m}$ ), medium (>500 $\mu \mathrm{m}$ : juvenile C. brachiatus $1152 \pm 252 \mu \mathrm{m}$ ) and small (>200 $\mu \mathrm{m}$ : Evadne spinifera $873 \pm$ $143 \mu \mathrm{m})$. (b) Frequency of bites at various times after food introduction. Points plotted are the means from 7 runs, error bars indicate $2 \mathrm{SD}$

\section{DISCUSSION}

The experiments reported here demonstrate that Sardinops sagax is able to capture food particles over a broad spectrum of prey sizes, from individual phytoplankton cells to large macrozooplankton, by either of 2 feeding modes. Pilchard capture their food primarily through non-selective filter-feeding (tow-net filtering, sensu Lazzaro 1987), although they are able to feed selectively when engaged in particulate-feeding.

Table 2. Statistical parameters for changes in relative abundance of 3 sizeclasses of wild zooplankton used as prey in a mixed food experiment

\begin{tabular}{|c|c|c|c|c|c|c|}
\hline \multirow{2}{*}{$\begin{array}{l}\text { Time } \\
\text { interval } \\
\text { (min) }\end{array}$} & \multicolumn{2}{|c|}{$>900 \mu \mathrm{m}$} & $>500 \mu \mathrm{m}$ & \multicolumn{2}{|c|}{ Size class } & $>200 \mu \mathrm{m}$ \\
\hline & $t$ & Sig. & $t$ & Sig & $t$ & Sig. \\
\hline $0-10$ & 5.544 & $p<0.001$ & 1.925 & $p<0.1$ & 4.733 & $p<0.001$ \\
\hline $10-20$ & 8.324 & $p<0.001$ & 2.677 & $\mathrm{p}<0.01$ & 4.470 & $p<0.001$ \\
\hline $20-30$ & 2.163 & $p<0.05$ & 1.783 & $p<0.1$ & 1.614 & $p<0.2$ \\
\hline
\end{tabular}

Several other clupeoid species exhibit both filterand particulate-feeding modes, depending on the size and concentration of available prey. Species that exhibit this feeding flexibility include Alosa pseudoharengus (Janssen 1976, 1978), Clupea harengus (Gibson \& Ezzi 1985, Batty et al. 1986), Dorosoma petenense (Holanov \& Tash 1978), Engraulis capensis (James \& Findlay 1989) and E. mordax (Leong \& O'Connell 1969, O'Connell 1972, Hunter \& Dorr 1982). These species generally filter-feed when presented with high concentrations of small particles (e.g. phytoplankton or small zooplankton) and particulate-feed on larger prey. To date only 1 clupeoid, Brevoortia tyrannus, has been shown experimentally to be an obligate filter-feeder (Durbin \& Durbin 1975), while no obligate particulate-feeding species have been reported.

Possession of 2 feeding modes, and the ability to rapidly switch back and forth between the two, must be highly advantageous in the patchy food environment inhabited by marine clupeoids, especially because the fish are likely to be faced with complex spatial and temporal variations in prey size-range and concentration. Food intake can thus be maximized in every situation, with the feeding mode which realizes the greatest return per unit effort being used in a given food environment (James \& Findlay 1989, Batty et al. 1990). The switch from filtering to biting (or vice versa) depends on the relative profitability of each mode (Gibson \& Ezzi 1992), and is influenced by particle size and concentration (Gibson \& Ezzi 1990), predator to prey size ratio and the relative concentrations of large and small prey (Crowder 1985), light intensity (Batty et al. 1990), and the relative energetic costs associated with each feeding mode. Hence, mode shifts to filterfeeding are more common when fish are large, prey are small and present in high concentrations, and light intensity is low. Mode shifts to particulate-feeding occur when fish are small, prey are large and present in low concentrations, and there is sufficient light for visual feeding (Crowder 1985).

Comparisons of feeding behaviour and rates between various clupeoid species are difficult to make because of the different experimental and analytical techniques used by various authors. However, there are similarities in feeding behaviour of the species examined. There appears to be a relationship between filter-bout duration of a particular species and development of the epibranchial gland, an organ considered responsible for food particle concentration in microphagous fish (Blaxter \& Hunter 1982). Species lacking epibranchial glands show filter bouts of 
relatively short duration (e.g. Clupea harengus 0.2 to 0.7 s, Gibson \& Ezzi 1985) whereas those possessing small epibranchial glands have filter bouts of intermediate duration (e.g. Alosa pseudoharengus 0.5 to $2 \mathrm{~s}$, Janssen 1976; Engraulis mordax 0.6 to $4.4 \mathrm{~s}$, Leong \& O'Connell 1969; E. capensis 0.4 to $3.0 \mathrm{~s}$, James \& Findlay 1989). Obligate filter-feeders such as Brevoortia tyrannus possess large epibranchial glands (Nelson 1967) and filter almost continuously (Durbin \& Durbin 1975). Therefore, development of the epibranchial gland in clupeoids appears to be related to the degree of microphagy (Blaxter \& Hunter 1982) and may possibly represent stages in a series progressing from facultative to obligate filterers. Pilchard filter bouts range from 0.2 to $4.6 \mathrm{~s}$, implying a well-developed epibranchial gland and a high degree of specialization towards microphagy.

When compared with other clupeoids, pilchard are highly efficient at retaining small particles. The particle size at which the clearance rate is half the predicted maximum when filtering $\left(F=50 \% F_{\max }\right)$ for pilchard is $200 \mu \mathrm{m}$ TL $\left(F=6.37 \mathrm{l} \mathrm{fish}^{-1} \mathrm{~min}^{-1}\right)$. This is in comparison to approximately $40 \mu \mathrm{m}$ TL $(F=2.58)$ fish $^{-1} \mathrm{~min}^{-1}$ ) for juvenile (Friedland et al. 1984) and $400 \mathrm{~mm}$ TL $\left(F=11.65 \mathrm{l} \mathrm{fish}^{-1} \mathrm{~min}^{-1}\right)$ for adult Brevoortia tyrannus (Durbin \& Durbin 1975), although the latter authors cautioned that their calculated $F_{\max }$ may have been an overestimate. Cape anchovy Engraulis capensis were unable to retain particles of less than $100 \mu \mathrm{m}$ maximum dimension (James \& Findlay 1989). The high retention efficiency for small particles exhibited by pilchard implies that this species is capable of exploiting both phytoplankton and microzooplankton as a food source.

The retention of small particles by pilchard is somewhat surprising, given that King \& Macleod (1976) found that the gill-raker gap in adult fish was approximately $300 \mu \mathrm{m}$. However, these authors concluded that overlap of the gill rakers on the second, third and fourth gill arches, and interlocking of the gill rakers on the upper and lower arches, significantly reduced the effective gill-raker gap. Retention of particles smaller than the minimum gill-raker gap has been reported for other marine filter-feeding planktivores (Nelson 1979 in Lazarro 1987), and is attributed to the importance of the denticle gaps and edges in collecting the smallest particles (Nelson 1979 in Lazarro 1987). Pilchard, in contrast to Cape anchovy, possess serrated denticles on their gill rakers (King \& Macleod 1976).
The fact that pilchard can entrap phytoplankton cells of small size, albeit with low efficiencies, means that they are capable of utilizing primary production directly, in addition to exploiting zooplankton as a food source. However, observations that some diatoms (e.g Thalassiosira weissflogii) are able to pass through the gastrointestinal tract without apparent digestion (unpubl. data) implies that utilization of phytoplankton may not be as efficient as supposed. The resistance of phytoplankton to fish digestion has been observed in several other fish (Lazarro 1987). In clupeoids, Velasquez (1939 in Lazarro 1987) and Smith (1963 in Lazarro 1987) found 46 genera of algae which survived passage through the gut of gizzard shad Dorosoma cepedianum.

Although pilchard are capable of both filter- and particulate-feeding, filter-feeding was the dominant feeding mode exhibited under experimental conditions. Particles of up to $1230 \mu \mathrm{m}$ TL were captured by filtering, regardless of concentration, at an average clearance rate of $11.781 \mathrm{fish}^{-1} \mathrm{~min}^{-1}$. Larger particles in high concentrations were also captured by filtering, but reduced concentrations of these large particles elicited a particulate-feeding response. A schematic representation of the feeding repertoire of pilchard compared to that of Cape anchovy is given in Fig. 9.

Field observations on the feeding and schooling behaviour of pilchard lend support to the hypothesis that filter-feeding is the dominant mode of food aquisition for this species. Schülein (pers. comm. in James $1988 \mathrm{~b}$ ) described a school of 500 to 700 fish, 10 to $30 \mathrm{~cm}$ apart, displaying strong filtering behaviour with '... their mouths and opercula widely expanded (like
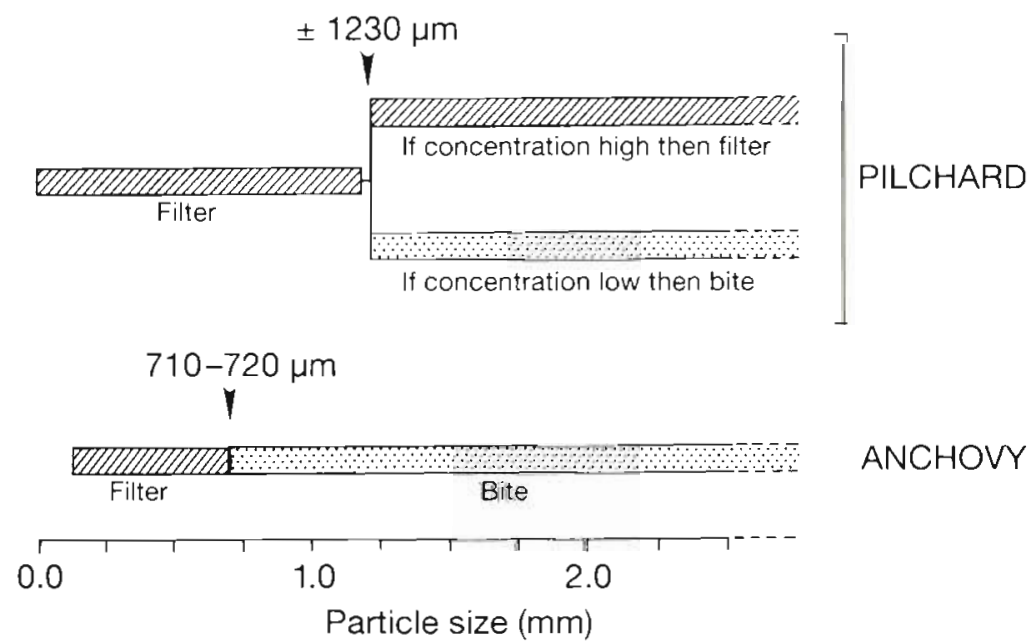

Fig. 9. Sardinops sagax, Engraulis capensis. Schematic representation of feeding behaviour as related to particle size for pilchard and for Cape anchovy (latter data from James \& Findlay 1989) 
wings), and each fish breaking the water surface. Davies (1957), after analysing 16600 stomachs, concluded that pilchard was primarily a filter-feeder, and considered this species to be phytophagous, having a mean stomach content ratio of $2: 1$ by volume of phytoplankton to zooplankton. Cushing (1978) erroneously assumed that Davies' (1957) mean ratio reflected surface area as opposed to volume; his suggestion that zooplankton were more significant in the diet than phytoplankton may therefore be false. King \& Macleod (1976) also considered pilchard to be primarily phytophagous and, finding no evidence of selective feeding behaviour, implied that the fish were filter-feeders only. This latter study was, however, limited to the inshore regions north of Walvis Bay, Namibia, an area typically high in phytoplankton biomass but with low densities of zooplankton (L. Hutchings, Sea Fisheries Research Institute, pers. comm.). The conclusions reached by King \& Macleod (1976) may, therefore, have been biased by locality.

The formation of fish schools has been seen as a mechanism for reducing predation pressure and facilitating reproduction (Partridge 1982). It has been suggested, however, that schooling of planktivorous fish occurs at the expense of foraging efficiency (Eggers 1976, Duffy \& Wissel 1988). This is due to the overlap of individual visual fields, resulting in a reduced prey-encounter rate for each fish. Therefore, particulate-feeding planktivores reduce their school density when feeding. It follows that filter-feeding (non-visual) planktivores would not have to reduce their school density to the same extent during feeding. Eggers (1976) further suggested that the costs of schooling are reduced if prey concentrations are high, if school size is small, or if distance between school members is high.

Cape anchovy rise to the surface and disperse at night, and descend and become aggregated during the day (Thomas \& Schülein 1988). Their feeding shows a marked synchronicity, peaking between dusk and midnight for juveniles on the west coast, and between midnight and dawn for adults on the south coast (James 1987). During these times, the anchovy are primarily engaged in particulate (i.e. visual) feeding (James 1987). Pilchard, in contrast, do not undertake significant diel vertical migration but tend to form small, scattered schools by night and dense schools by day (Hampton et al. 1979, Thomas \& Schülein 1988), generally remaining in the top $20 \mathrm{~m}$ of the water column. Therefore pilchard appear to balance the gains from schooling (protection, ease of reproduction) against the costs (reduced prey consumption) by predominantly filtering in small schools, the maximum size of which is limited by food abundance (Duffy \& Wissel 1988).
Particulate-feeding by pilchard is most probably restricted to fish on the periphery of the school, because it is doubtful that large prey items would be able to infiltrate the school without detection by these peripheral fish. The proportion of food captured by particulate-feeding is therefore likely to be negligible compared to that captured by filter-feeding, unless the fish continually change position within the school.

Consumption rates and, hence, time to attain daily ration for pilchard may be derived from biomass estimates of southern Benguela zooplankton. Estimates of mesozooplankton biomass have been provided by several authors (e.g. Andrews \& Hutchings 1980, Pillar 1984a, b, Hutchings 1985, Peterson et al. 1990, Verheye 1991), but microzooplankton estimates are scarce. Armstrong et al. (1987) reported the densities of copepodites, nauplii and copepod eggs, which they

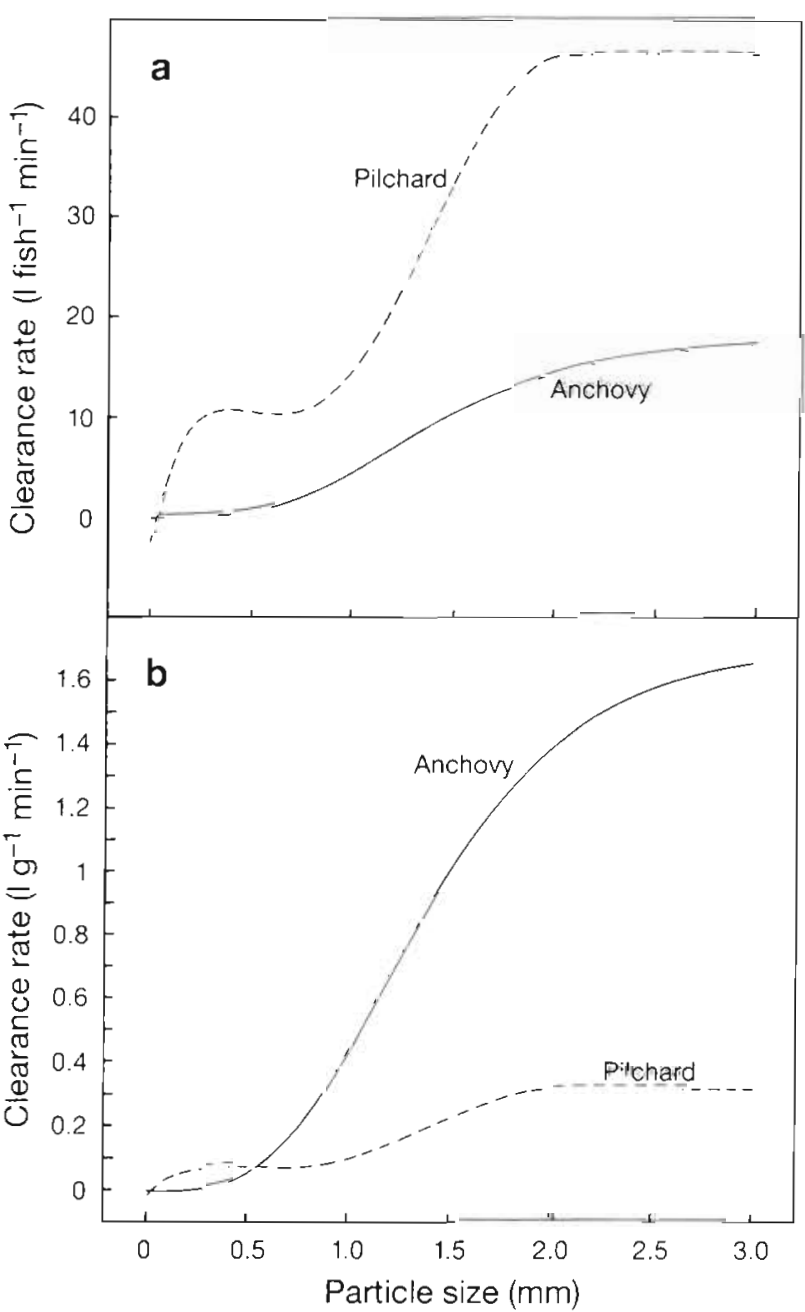

Fig. 10. Sardinops sagax, Engraulis capensis. Predicted clearance rates $(F)$ as a function of particle size for pilchard and Cape anchovy. (a) $F$ expressed on a per-fish basis. (b) $F$ expressed on a per-gram basis, i.e. weight standardized. Data for E. capensis from James \& Findlay (1989) 
Fig. 11 Sardinops sagax, Engraulis capensis. Schematic representation of resource partitioning between pilchard and Cape anchovy. Arrow size reflects the perceived importance of specific components (e.g. mesozooplankton) in the diet of each species

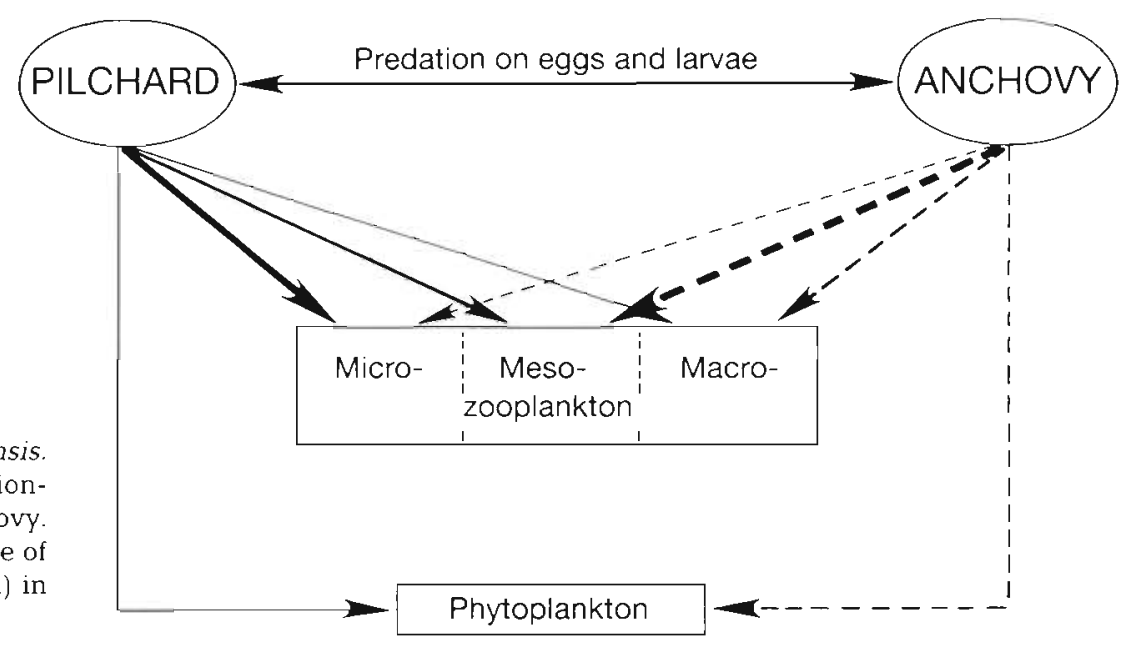

found dominated the zooplankton fraction of microplankton samples from an upwelling front in the southern Benguela. Using the maximum density isopleths provided by Armstrong et al. (1987) for each of the 3 groups $\left(30,300\right.$ and $601^{-1}$ respectively) and assigning dry weights of 860,83 and $56 \mathrm{ng}^{-1} \mathrm{~d}^{-1}$ respectively (Beers 1966 for copepodites and nauplii; J. Huggett, Sea Fisheries Research Institute, pers. comm. for eggs) allows an estimate of maximum microzooplankton biomass to be made $\left(54.2 \mu \mathrm{g}\right.$ dry wt $\left.\mathrm{l}^{-1}\right)$. Proportions of $25 \%, 50 \%$ and $100 \%$ of this maximum value were combined with the average mesozooplankton biomass $\left(54.5 \pm 51.8 \mu \mathrm{g}\right.$ dry wt $\left.\mathrm{l}^{-1} ; \mathrm{n}=29\right)$ to give estimates of the quantity of zooplankton food available to filter-feeding pilchard. Using clearance rates of $11.78 \mathrm{l} \mathrm{fish}^{-1} \mathrm{~min}^{-1}$ for mesozooplankton and $5.1 \mathrm{l}$ fish $^{-1} \mathrm{~min}^{-1}$ for microzooplankton enables an estimation of the ingestion rates of filter-feeding pilchard under these 3 food environments to be made. The resuitant calculations indicate that pilchard are able to obtain their daily requirement $\left(10 \%\right.$ wet body wt $\mathrm{d}^{-1}$, Shannon \& Field 1985 ; or 2 to $3 \%$ dry body wt $d^{-1}$, Armstrong et al. 1991) in 6 to $12 \mathrm{~h}$ (depending on the biomass of microzooplankton present) exclusively through filter-feeding on meso- and microzooplankton. Because of the uncertainty concerning the digestibility and hence assimilation of diatoms by pilchard, estimates of phytoplankton biomass have not been included in the above calculations. Any energy gained by pilchard through ingesting phytoplankton will have the effect of reducing the time required to attain daily ration to less than $12 \mathrm{~h}$.

Predictive equations of clearance rate as a function of particle size can be used to facilitate comparisons between pilchard and Cape anchovy, species that coexist in both the Benguela and the Agulhas Current off the southern African coast. On a per-fish basis, pilchard show much higher clearance rates than anchovy (Fig. 10a). However, when rates are standardized and expressed as a function of fish weight, pilchard are only more efficient at removing particles of less than $580 \mu \mathrm{m}$ TL, anchovy having distinctly faster clearance rates on particles larger than this size (Fig. 10b). This difference strongly implies resource partitioning between the 2 species, in contrast to previous suggestions of competition between coexisting species pairs of sardine and anchovy (Lasker \& MacCall 1983, Lasker 1985). Therefore, as a result of different feeding strategies, pilchard are more efficient removers of small particles, while anchovy remove large particles more effectively (Fig. 11).

Acknowledgements. I thank Dr L. V. Shannon, Director of the Sea Fisheries Research Institute (SFRI), for funds and facilities for this research. Particular thanks to Anastasia Polito for her assistance with experiments and untiring video analysis, and to Envor Malan for fish and food organism maintenance. Thanks are also due to Alan Kemp, Andre du Randt, Alistair Busby and Deon Horstman for collecting wild zooplankton, and to Jan Korrubbel for generating the polynomial regression. Drs L. Hutchings, G. Pitcher, M. J. Gibbons and Ms R. Wynberg, and 3 anonymous referees are warmly acknowledged for valuable comments on early drafts of the manuscript.

\section{LITERATURE CITED}

Andrews, W. R. H., Hutchings, L. (1980). Upwelling in the southern Benguela current. Prog. Oceanogr. 9: 1-81

Armstrong, D. A., Mitchell-Innes, B. A., Verheye-Dua, F., Waldron, H., Hutchings, L. (1987). Physical and biological features across an upwelling front in the southern Benguela. In: Payne, A. I. L., Gulland, J. A., Brink, K. H. (eds.) The Benguela and comparable ecosystems. S. Afr. J. mar. Sci. 5: 171-190

Armstrong, M. J., Thomas, R. M. (1989). Clupeoids. In: Payne, A. I. L., Crawford, R. J. M. (eds.) Oceans of life off southern Africa. Vlaeberg, Cape Town, p. 105-121

Armstrong, M. J., James, A. G., Valdes-Szeinfeld, E. S. (1991). Estimates of annual consumption of food by anchovy and 
other pelagic fish species off South Africa during the period 1984-1988. S. Afr. J. mar. Sci. 11: 251-266

Batty, R. S., Blaxter, J. H. S., Libby, D. A. (1986). Herring (Clupea harengus) filter-feeding in the dark. Mar. Biol. 91: $371-375$

Batty, R. S., Blaxter, J. H. S., Richard, J. M. (1990). Light intensity and feeding behaviour of herring, Clupea harengus. Mar. Biol. 107: 383-388

Beers, J. R. (1966). Studies on the chemical composition of the major zooplankton groups in the Sargasso Sea off Bermuda. Limnol. Oceanogr. 11: 520-528

Blaxter, J. H. S., Hunter, J. R. (1982). The biology of the clupeoid fishes. Adv mar. Biol. 20: 1-223

Crowder, L. B. (1985). Optimal foraging and feeding mode shifts in fishes. Environ. Biol. Fish. 12:57-62

Cushing, D. H. (1978). Upper trophic levels in upwelling areas. In: Boje, R., Tomczak, M. (eds.) Upwelling ecosystems. Springer-Verlag, New York, p. 101-110

Davies, D. H. (1957). The South African pilchard (Sardinops ocellata). Preliminary report on feeding off the west coast, 1.953-56. Investl Rep. Div. Fish. Un. S. Afr. 30: 1-40

Duffy, D. C., Wissel, C. (1988). Models of fish school size in relation to environmental productivity. Ecol. Modelling 40: $201-211$

Durbin, A. G., Durbin, E. G. (1975). Grazing rates of the Atlantic menhaden Brevoortia tyrannus as a function of particle size and concentration. Mar. Biol. 33: 265-277

Eggers, D. M. (1976). Theoretical effect of schooling by planktivorous fish predators on rate of prey consumption. J. Fish. Res. Bd Can. 33: 1964-1971

Friedland, K. D., Haas, L. W., Merriner, J V. (1984). Filtering rates of the juvenile Atlantic menhaden Brevoortia tyrannus (Pisces: Clupeidae) with consideration of the effects of detritus and swimming speed. Mar. Biol. 84: 109-117

Frost, B. W. (1972). Effects of size and concentration of food particles on the feeding behaviour of the marine planktonic copepod Calanus pacificus. Limnol. Oceanogr. 17: $805-815$

Gibson, R. N., Ezzi, I. A. (1985). Effect of particle concentration on filter- and particulate-feeding in the herring Clupea harengus. Mar. Biol. 88: 109-116

Gibson, R. N., Ezzi, I. A. (1990). Relative importance of prey size and concentration in determining the feeding behaviour of the herring Clupea harengus. Mar. Biol. 107: 357-362

Gibson, R. N., Ezzi, I. A. (1992). The relative profitability of particulate- and filter-feeding in the herring. Clupea harengus L. J. Fish Biol. 40: 577-590

Hampton, I., Agenbag, J. J., Cram, D. L. (1979). Feasibility of assessing the size of the South West African pilchard stock by combined aerial and acoustic measurements. Fish. Bull. S. Afr $11.10-22$

Holanov, S. H., Tash, J. C. (1978). Particulate and filter feeding in threadfin shad, Dorosoma petenense, at different light intensities. J. Fish Biol. 13: 619-625

Hunter, J. R., Dorr, H. (1982). Thresholds for filter feeding in northern anchovy, Engraulis mordax. Rep. Calif. coop. oceanic Fish. Invest. 13: 198-204

Hutchings, L. (1985). Vertical distribution of mesozooplankton at an active upwelling site in the southern Benguela current, December 1969. Investl Rep. Sea Fish. Res. Inst. S. Afr. 129: 1-67

James, A. G. (1987). Feeding ecology, diet and field-based studies on feeding selectivity of the Cape anchovy Engraulis capensis Gilchrist. In: Payne, A. 1. L., Gulland, J. A., Brink, K. H. (eds.) The Benguela and comparable ecosystems. S. Afr. J. mar. Sci. 5: 597-611

James, A. G. (1988a). Are clupeoid microphagists herbivorous or omnivorous? A review of the diets of some commercially important clupeids. S. Afr. J. mar. Sci. 7: 161-177

James, A. G. (1988b). The feeding ecology of and carbon and nitrogen budgets for Engraulis capensis in the southern Benguela ecosystem. Ph.D. thesis, University of Cape Town

James, A. G., Findlay, K. P. (1989). Effect of particle size and concentration on feeding behaviour, selectivity and rates of food ingestion by the Cape anchovy Engraulis capensis. Mar. Ecol. Prog. Ser. 50: 275-294

Janssen, J. (1976). Feeding modes and prey size selection in the alewife (Alosa pseudoharengus). J. Fish. Res. Bd Can. 33: $1972-1975$

Janssen, J. (1978). Feeding behaviour repertoire of the alewife, Alosa pseudoharengus, and the ciscoes Coregonus hoyi and C. artedii. J. Fish. Res. Bd Can. 35: 249-253

King, D. P. F., Macleod, P. R. (1976). Comparison of the food and filtering mechanism of pilchard Sardinops ocellata and anchovy Engraulis capensis off South West Africa, 1971 - 1972. Investl Rep. Sea Fish. Brch S. Afr. 111: 1-29

Lasker, R. (1985). What limits clupeoid production? Can. J. Fish. Aquat. Sci. 42: 31-38

Lasker, R., MacCall, A. (1983). New ideas on the fluctuations of the clupeoid stocks off California. Proc. Joint Oceanogr. Assembly 1982 - General symposia. Can. Nat. Comm./ Scientific Comm. Ocean. Res, Ottawa, p. 110-120

Lazzaro, X (1987). A review of planktivorous fishes: their evolution, feeding behaviours, selectivities, and impacts Hydrobiologia 146: 97-167

Leong, R. J., O'Connell, C. P. (1969). A laboratory study of particulate and filter feeding of the northern anchovy. Engraulis mordax. J. Fish. Res. Bd Can. 26: 557-582

Lluch-Belda, D., Crawford, R. J. M., Kawasaki, T., MacCall A. D., Parrish, R. H., Schwartzlose, R. A., Smith, P. E (1989). World-wide fluctuations of sardine and anchovy stocks: the regime problem. S. Afr. J. mar. Sci. 8: 195-205

Nelson, G. J. (1967). Epibranchial organs in lower teleostean fishes. J. Zool., Lond. 153: 71-89

O'Connell, C. P. (1972). The interrelation of biting and filtering in the feeding activity of the northern anchovy (Engraulis mordax). J. Fish. Res. Bd Can. 29: 285-293

Parrish, R. H., Serra, R., Grant, W. S. (1989). The monotypic sardines, Sardina and Sardinops: their taxonomy, distribution, stock structure and zoogeography. Can. J. Fish. Aquat. Sci. 46: 2019-2036

Partridge, B. L. (1982). The structure and function of fish schools. Scient. Am. 246: 90-99

Peterson, W. T., Hutchings, L., Huggett, J. A., Largier, J. L. (1992). Anchovy spawning in relation to the biomass and the replenishment rate of their copepod prey on the western Agulhas Bank. In: Payne, A. I. L., Brink, K. H., Mann, K. H., Hilborn, R. (eds.) Benguela trophic functioning. S. Afr. J. mar. Sci. 12: $487-500$

Peterson, W. T., Painting, S. J., Hutchings, L. (1990). Diel variations in gut pigment content, diel vertical migration and estimates of grazing impact for copepods in the southern Benguela upwelling region in October 1987 J. Plankton Res. 12: 259-281

Pillar, S. C. (1984a). A comparison of the performance of four zooplankton samplers. S. Afr. J. mar. Sci. 2: 1-18

Pillar, S. C. (1984b). Diel variation in the vertical distribution of some common zooplankton species off the west coast of South Africa. S. Afr. J. mar. Sci. 2: 71-80

Seale, D. B., Beckvar, N. (1980). The comparative ability of anuran larvae (genera: Hyla, Bufo and Rana) to ingest suspended blue-green algae. Copeia 1980: 495-503

Shannon, L. V., Field, J. G. (1985). Are fish stocks food-limited 
in the southern Benguela pelagic ecosystem? Mar Ecol. Prog. Ser. 22: 7-19

Thomas, R. M., Schülein, F. H. (1988). The shoaling behaviour of pelagic fish and the distribution of seals and gannets off Namibia as deduced from routine fishing reports, 1982-1985. S. Afr. J. mar. Sci. 7: 179-191

This article was submutted to the editor
Verheye, H. M. (1991). Short-term variability during an anchor station study in the southern Benguela upwelling system: abundance, distribution and estimated production of mesozooplankton with special reference to Calanoides carinatus (Kroyer, 1849). Prog. Oceanogr 28: $91-119$

Manuscripl first received: June 25, 1993

Revised version accepted: February 22, 1994 